\title{
A Clinical Comparision between Ropivacaine-Clonidine Combination and Ropivacaine (Plain) in Brachial Plexus Block by Supraclavicular Approach
}

\author{
Virupakshamma', Shivaraddi Bhandi' \\ ${ }^{1}$ Senior Resident, Department of Anesthesiology, Gadag Institute of Medical sciences, Gadag, Karnataka, ${ }^{2}$ Assistant Professor, Department of \\ Anesthesiology, Gadag Institute of Medical sciences, Gadag, Karnataka.
}

\section{Abstract}

Background: Ropivacaine is a long-acting amide local anaesthetic agent and first produced as a pure enantiomer. It produces effects similar to other local anaesthetics via reversible inhibition of sodium ion influx in nerve fibres. Ropivacaine is less lipophilic than bupivacaine and is less likely to penetrate large myelinated motor fibres, resulting in a relatively reduced motor blockade. Thus, ropivacaine has a greater degree of motor sensory differentiation, which could be useful when motor blockade is undesirable. The reduced lipophilicity is also associated with decreased potential for central nervous system toxicity and cardiotoxicity. Subjects and Methods: This study was conducted on 60 patients undergoing upper limb surgeries aged between 18 to 55 years under supraclavicular block and informed written consent was taken. Result values were recorded using a preset proforma. Results: The mean duration of motor block in group RC was 10.10+/- 0.68 hours and the group $\mathrm{R}$ was $6.69+/-0.65$ hours. The statistical analysis by students unpaired , te test showed that the difference between duration of motor block in group RC was significantly longer when compared to group R ( $<0.001)$. Conclusion: The addition of Clonidine $(150 \mu \mathrm{g})$ as an adjuvant to Ropivacaine $(0.75 \%)$ has faster onset of sensory and motor block and longer duration of sensory and motor block.

Keywords: Brachial Plexus Block, Supraclavicular Approach, Ropivacaine.

Corresponding Author: Dr. Shivaraddi Bhandi, Assistant Professor, Department of Anesthesiology, Gadag Institute of Medical sciences, Gadag, Karnataka.

Received: February 2019

Accepted: February 2019

\section{Introduction}

Brachial plexus blocks provide a useful alternative to general anaesthesia for upper limb surgeries. They achieve near ideal operating conditions by producing complete muscular relaxation, maintaining stable intra-operative haemodynamics and the associated sympathetic block. The sympathetic block decreases post-operative pain, vasospasm, and edema. ${ }^{[1]}$

Ropivacaine is a long-acting amide local anaesthetic agent and first produced as a pure enantiomer. It produces effects similar to other local anaesthetics via reversible inhibition of sodium ion influx in nerve fibres. Ropivacaine is less lipophilic than bupivacaine and is less likely to penetrate large myelinated motor fibres, resulting in a relatively reduced motor blockade. Thus, ropivacaine has a greater degree of motor sensory differentiation, which could be useful when motor blockade is undesirable. The reduced lipophilicity is also associated with decreased potential for central nervous system toxicity and cardiotoxicity. ${ }^{[2]}$

Clonidine, is an imidazoline alpha-2 adrenergic agonist mainly used as an anti-hypertensive agent. Alpha-2A receptors mediate sedation, analgesia, and sympatholysis.
Clonidine is known to produce anti-nociception and enhance the effect of local anaesthetics when given intrathecally, epidurally and in peripheral nerve blocks. ${ }^{[2]}$ Clonidine produces this effect by modulating pain pathways through presynaptic alpha-2A adrenergic receptors. ${ }^{[3]}$ It also produces sedation through acting on pontine locus ceruleus where highest density of alpha- 2 receptors are present. ${ }^{[4]}$

So the present study is being undertaken to evaluate the onset time, duration and analgesic efficacy of clonidineropivacaine combination compared to plain ropivacaine $(0.75 \%)$ for brachial plexus block by supraclavicular approach.

\section{Subjects and Methods}

This study was conducted on 60 patients undergoing upper limb surgeries aged between 18 to 55 years under supraclavicular block and informed written consent was taken. Result values were recorded using a preset proforma.

\section{Investigations Required}

- $\mathrm{Hb} \%, \mathrm{TC}, \mathrm{DC}, \mathrm{BT}, \mathrm{CT}$.

- Blood grouping 
- RBS, Blood urea and serum creatinine

- Chest x-ray, ECG

- HIV, HBsAg

\section{Preliminaries}

- Written informed consent.

- Intravenous access with a 20 gauge I.V cannula on the contralateral upper limb under aseptic techniques.

\section{Equipment's}

\section{a) For the procedure}

A portable tray covered with sterile towels containing:

- Sterile syringes - one $20 \mathrm{ml}$ and one $10 \mathrm{ml}$.

- Bowl containing Povidone iodine and spirit.

- $\quad$ Sponge holding forceps.

- Towels and towel clips.

- $\quad$ Sterile gauze pieces.

\section{a) For emergency resuscitation :}

The anaesthesia machine, emergency oxygen source (E type cylinders), pipeline $\mathrm{O} 2$ supply, working laryngoscopes, appropriate size endotracheal tubes and connectors.

- Working suction apparatus with suction catheter.

- Oropharyngeal airways.

- Intravenous fluids.

○ Drugs: Thiopentone, Diazepam, Succinylcholine, Hydrocortisone, Atropine, Adrenaline, Aminophylline, Mephenteramine, Calcium gluconate and Sodium bicarbonate.

\section{b) Monitors :}

- Pulse oximeter.

- Noninvasive blood pressure monitor by sphygmomanometer on the opposite upper limb.

Procedure: A prospective, randomized, single blinded study would be undertaken. 60 patients posted for upper limb surgeries under supraclavicular block would be assigned to 2 groups, each containing 30 patients.

- Control group - Group R: Would receive $30 \mathrm{ml}$ of ropivacaine $0.75 \%$

- Study group-Group RC: Would receive $30 \mathrm{ml}$ of ropivacaine $(0.75 \%)+1 \mathrm{ml}$ of clonidine $(150 \mu \mathrm{g})$.

- Patient lies supine, arms by the side and head turned slightly to the other side.

- The interscalene groove and mid-point of clavicle would be identified.

- After aseptic preparation of area, at a point 1.5 to $2.0 \mathrm{~cm}$ posterior and cephalad to mid-point of clavicle, subclavian artery pulsations are felt. A skin wheel is raised with local anaesthetic just cephalo-posterior to the pulsations.

- Next, a 22 gauge, $5 \mathrm{~cm}$ needle, mounted on a $20 \mathrm{ml}$ syringe, would be passed through the same point, parallel to the head and neck, in a caudal, slightly medial and posterior direction, until either paraesthesia was elicited or first rib was encountered.

- If the first rib is encountered, the needle would be moved over the first rib until a paraesthesia was elicited either in the hand or arm.

- After eliciting paraesthesia and negative aspiration of blood, the study medication would be injected.
- All patients would be monitored for anaesthesia and analgesia upto 24 hours post-operatively.

- Sensory block was evaluated by temperature testing using spirit soaked cotton on skin dermatomes $\mathrm{C} 4$ to T2where as motor block was assessed by asking the patient to adduct the shoulder and flex the forearm against gravity.

- Onset of sensory block was defined as the time elapsed between injection of drug and complete loss of cold perception of the hand, while onset of motor blockade was defined as the time elapsed from injection of drug to complete motor block.

- Heart rate, non-invasive blood pressure and O2 saturation were also monitored.

- Duration of sensory block (the time elapsed between injection of drug and appearance of pain requiring analgesia) and duration of motor block (the time elapsed between injection of drug and complete return of muscle power) would also be recorded.

- IM injection of Diclofenac sodium would be given as rescue analgesic when patients complain of pain.

- Quantitative data will be analysed by student's 't' test.

- Qualitative data will be analysed by Chi-square test.

- $\mathrm{P}$ value $<0.05$ would be considered statistically significant.

\section{Results}

Table 1: Time for onset of sensory block (min)

\begin{tabular}{|l|l|l|l|}
\hline Study group & Onset time (min) & P value & Significance \\
\hline $\mathrm{R}$ & $10.83+/-1.05$ & $\mathrm{P}<0.001$ & $\mathrm{HS}$ \\
\cline { 2 - 2 } $\mathrm{RC}$ & $5.30+/-1.02$ & & \\
\hline
\end{tabular}

The mean time for onset of sensory block in group RC was $5.30+/-1.02 \mathrm{~min}$ and in group $\mathrm{R}$ was $10.83+/-1.05 \mathrm{~min}$. The statistical analysis by student ${ }^{\text {ec }}$ s unpaired „te test showed that, the time for onset of sensory block in group RC was significantly faster when compared to group $\mathrm{R}(\mathrm{P}<0.001)$.

Table 2: Time for onset of motor block (min)
\begin{tabular}{|l|l|l|l|}
\hline Study group & Onset time (min) & P value & Significance \\
\hline R & $13.87+/-1.33$ & P $<0.001$ & HS \\
\hline RC & $7.87+/-1.33$ & & \\
\hline & $*$ Student"s unpaired t test HS - Highly significant \\
\hline
\end{tabular}

The mean time for onset of motor block in group $\mathrm{R}$ was $13.87+/-1.33 \mathrm{~min}$ and in group $\mathrm{RC}$ was $7.87+/-1.33 \mathrm{~min}$. The statistical analysis by unpaired student ${ }^{\text {ee }}$,"te test showed that, the time for onset of motor block was significantly faster when compared to group $\mathrm{R}(\mathrm{P}<0.001)$.

Table 3: Duration of sensory block (hours)
\begin{tabular}{|l|l|l|l|}
\hline Study group & $\begin{array}{l}\text { Duration of block } \\
\text { (hrs) }\end{array}$ & P value & Significance \\
\hline R & $8.01+/-0.64$ & P $<0.001$ & HS \\
\hline RC & $11.42+/-0.6$ & & \\
\hline * Student"s unpaired t test HS - Highly significant
\end{tabular}

Patients of both groups were observed for 24 hours. Time was noted when the patient asked for rescue analgesics. The 
mean duration of sensory block in group RC was $11.42+/-$ 0.6 hours and in group $\mathrm{R}$ was $8.01+/-0.64$ hours. The statistical analysis by students unpaired , $\mathrm{t}^{\text {te }}$ test showed that the duration of sensory block in group RC was significantly longer when compared to group $\mathrm{R}(\mathrm{P}<0.001)$.

Table 4: Duration of motor block (hours)

\begin{tabular}{|l|l|l|l|}
\hline Study group & $\begin{array}{l}\text { Duration of block } \\
\text { (hrs) }\end{array}$ & P value & Significance \\
\hline $\mathrm{R}$ & $6.69+/-0.65$ & $\mathrm{P}<0.001$ & $\mathrm{HS}$ \\
\hline $\mathrm{RC}$ & $10.10+/-0.68$ & & \\
\hline * Student"s unpaired t test HS - Highly significant
\end{tabular}

The mean duration of motor block in group RC was $10.10+/-$ 0.68 hours and the group $\mathrm{R}$ was $6.69+1-0.65$ hours. The statistical analysis by students unpaired ,te test showed that the difference between duration of motor block in group $\mathrm{RC}$ was significantly longer when compared to group $\mathrm{R}(\mathrm{P}<$ $0.001)$.

\section{Discussion}

A total of 60 patients within the age group of 18-55 were included in the study, 30 in each group. Out of which the mean age of group $\mathrm{R}$ (receiving only Ropivacaine) was $33.87+/-9.86$ years and the mean age of group RC (receiving Clonidine with Ropivacaine) was 33.67+/- 11.59 years. Hence both groups were comparable in regard to age. Male to female ratio was almost same.

In our study we found that the onset of sensory and motor blocks was significantly faster in patients who received a combination of Clonidine and Ropivacaine. Onset of sensory block (group RC, 5.30+/- 1.02 min; group R, 10.83+/-1.05 min). Onset of motor block (group RC, 7.87+/- 1.33 min; group $\mathrm{R}, 13.87+/-1.33 \mathrm{~min})$.

This could be due to a local direct action of Clonidine and its synergistic action with that of local anaesthetics. The onset of sensory block was found to be faster than the onset of motor block in both groups.

Our results showed that sensory block tended to last longer as compared to motor block which agrees with the observation by de Jong et al. ${ }^{[5]}$ These authors explained that large fibres require a higher concentration of local anaesthetic than small fibres. The minimal effective concentration of local anaesthetic for large (motor) fibres is greater than for small (sensory) fibres. Thus, motor function return before pain perception and duration of motor block is shorter than the sensory block. In our study duration of motor block was prolonged when clonidine was added to ropivacaine. (group RC, 10.10+/- 0.68 hrs; group R, 6.69+/0.65 hrs).

In our study, the mean duration of sensory block (i.e. time elapsed from time of injection to appearance of pain requiring analgesia) was significantly higher $(\mathrm{P}<0.05)$ in group $\mathrm{RC}$ than in group R. (group RC, 11.42+/- $0.6 \mathrm{hrs}$; group R, 8.01+/-0.64hrs).

A prospective, randomized, double blind, controlled study was conducted by Rohan B et al. ${ }^{[6]}$ to assess the efficacy of Clonidine as an adjuvant to Ropivacaine in brachial plexus block. 75 patients undergoing upper limb surgery under supraclavicular brachial plexus block were allocated into three groups of 25 each.

- Group $\mathrm{A}(\mathrm{n}=25)$ received $20 \mathrm{ml}$ of $0.75 \%$ Ropivacaine
- Group $\mathrm{B}(\mathrm{n}=25)$ received $20 \mathrm{ml}$ of $0.75 \%$ Ropivacaine plus $150 \mathrm{~g}$ Clonidine

- Group $\mathrm{C}(\mathrm{n}=25)$ received $20 \mathrm{ml}$ of $0.75 \%$ Ropivacaine plus $10 \mathrm{ml}$ of $2 \%$ lignocaine with adrenaline $(1 ; 2,00,000)$. The mean onset of sensory block (group A, 8.72+/- 1.13 min, group B, 5.84+/- 0.55 min, group C, $3.84+/-O .80$ min ) and motor block (group A, 10.08+/- 0.90 min; group B, 6.80 $+/-1.00 \mathrm{~min}$ ) was significantly faster in group B than in group $\mathrm{A}(\mathrm{P}<0.001)$. The duration of analgesia (group A, $227.44+/-36.27$ min, group B, 450.08+/- 54.45min) was also longer in group B than in group $\mathrm{A}$. the duration of motor block (group A 172.64+/- 40.86 min, group B, 368.56 +/$59.68 \mathrm{~min}$ ) was also longer in group $B$ than in group $A$. These results are comparable with our study.

Various studies in which Clonidine was used in peripheral nerve block found that Clonidine with Ropivacaine improves analgesic characteristics compared to Ropivacaine alone. ${ }^{[7,8]}$ Siddarth Srban et al, ${ }^{[9]}$ found that a Ropivacaine and Clonidine combination increases the onset and duration of motor and sensory block compared to a Ropivacaine alone when administered for brachial plexus block. Giovanni Cucchiaro10 et al evaluated the effects of adding clonidine on the duration of sensory and motor block and analgesia time in children who underwent a variety of peripheral nerve blocks and concluded that the addition of clonidine to Ropivacaine can extend duration of sensory and motor blocks.

\section{Conclusion}

From our study, we conclude that, the addition of Clonidine $(150 \mu \mathrm{g})$ as an adjuvant to Ropivacaine $(0.75 \%)$ has following effects :

- Faster onset of sensory block.

- Faster onset of motor block.

- Longer duration of sensory block.

- Longer duration of motor block.

\section{References}

1. David L. Brown and L. Donald Bridenbangh.’'The upper extremity somatic block". chapter-10,neural blockade in clinical anaesthesia and management of pain,3rd edn, Edit. M.J. Cousins and P.O. Bridenbaugh Philadelphia;Lippincot-Raven,1998;348-372.

2. Michael F.Mulroy „Peripheral nerve blockade” chapter-27,clinical anaesthesia,4th edn, Edt, Paul G. Barash, Bruce F. Cullen and Robert K.Stoelting,2001;723-727

3. Maria Matuszezak "Supraclavicular block “.chapter -6.Peripheral nerve blocks by Jacques E .Chelly,1999;35-38.

4. David L.Brown, "Upper Extremity block anatomy". chapter -2,in atlas of regional anaesthesia 2nd Edn, W.B.Saunders company,1999;13-22

5. De Jong RH, Wagman IH, Physiological mechanism of peripheral nerve block by local anaesthetics. Anesthesiology 1963;24:684-727.

6. Rohan B, Singh PY, Gurjeet K. Addition of Clonidine or lingocaine to ropivacaine for supraclavicular brachial plexus block: a comparative study. Singapore Med. J. 2014 April; 55(4): 229-32.

7. Jaiswal Rajmala, Bansal Teena, Mehta Sandeep, Ahlawat Geeta; A Study to evaluate the effect of adding clonidine to ropivacaine for axillary plexus blockade; vol 6,suppl 3,2013.

8. Casati A, Magistris L, Beccaria P, Cappelleri G, Aldegheri G, Fanelli $\mathrm{G}$; Improving postoperative analgesia after axillary brachial plexus block with $0.75 \%$ ropivacaine; A double blind evaluation of adding clonidine. Minerva Anestesiol.,2001;67: 407-412.

9. Dr. Sidharth Sraban routray, Dr Debdas Biswal. The Effect of Clonidine on ropivacaine in supraclavicular brachial plexus block. Sch. J. App. Med. Sci., 2013; 1(6):887-893. 
10. Cucchiaro G, Ganesh A; The effects of clonidine on postoperative analgesia,2007;104(3):532-537. analgesia after peripheral nerve blockade in children. Anesthesia and

Copyright: () the author(s), publisher. Academia Anesthesiologica International is an Official Publication of "Society for Health Care \& Research Development". It is an open-access article distributed under the terms of the Creative Commons Attribution Non-Commercial License, which permits unrestricted non-commercial use, distribution, and reproduction in any medium, provided the original work is properly cited.

How to cite this article: Virupakshamma, Bhandi S. A Clinical Comparision between Ropivacaine-Clonidine Combination and Ropivacaine (Plain) in Brachial Plexus Block by Supraclavicular Approach. Acad. Anesthesiol. Int. 2019;4(1):1-4.

DOI: dx.doi.org/10.21276/aan.2019.4.1.1

Source of Support: Nil, Conflict of Interest: None declared. 